This is an electronic reprint of the original article. This reprint may differ from the original in pagination and typographic detail.

Please cite the original version: P. Lehto, A. Ainamo, J. Porokuokka (2018) The Role of Master's Level Students Case Robots and Future of Welfare Services, ICERI2018 Proceedings, pp. 6986-6992.

doi: $10.21125 /$ iceri.2018.0267 


\title{
THE ROLE OF MASTER'S LEVEL STUDENTS - CASE ROBOTS AND FUTURE OF WELFARE SERVICES
}

\author{
Lehto Paula ${ }^{1}$, Antti Ainamo², Jaakko Porokuokka ${ }^{3}$ \\ ${ }^{1} \mathrm{PhD}$ (Laurea University of Applied Sciences, Finland) \\ ${ }^{2} \mathrm{PhD}$ (Laurea University of Applied Sciences, Finland) \\ ${ }^{3} \mathrm{MBA}$ (Laurea University of Applied Sciences, Finland)
}

\begin{abstract}
In a modern society, there are three general strategies used to integrate academic education with working-life requirements together. These strategies are education, development of curricula, and developing models of future learning [1]. Some methods used to bring these general strategies to life include designing of new ICT applications and digital services, as well as developing and improving upon established models of learning, applications and services. A commonly faced challenge is that new applications, new services and new ways of learning have been perceived as an excessively massive change in the context of the overall system in which these changes take place. Introduction of robots and software interfaces that operate between care professionals and clients is considered to be one such massive change in the overall ecosystem of health care and social welfare. Educating professionals or clients to go along with massive changes in the system is not an easy task. Personal one-to-one service is taken as granted by many. It is considered to be a nonnegotiable element of their client identity, professional identity, or both. This paper is based on a vision that future generations of professionals will have competences, roles and qualifications that are not evident in current, traditional or textbook-healthcare and wellbeing services. We believe that future health care and social welfare professionals will be solving real-life problems and challenges, and building competences towards this scenario should start during their studies.

This paper describes and explains what kinds of roles Master's-level students had in an ongoing academic research project through their participation in a Master's-level study course, titled "Research, social robots and concept development". This course was a part of a research project "Robots and the future of welfare services". During the course, a robot was placed in a "living lab" setting $[12,13,14,17]$ to participate in giving care to elderly citizens. The students participating the course learned to discover new roles for themselves, to generate ideas, and to gain new competences in the context of the academic-research project, the study course, and towards their future careers.
\end{abstract}

Keywords: Competences, Learning, Living lab, Master's level education, Robot 


\section{INTRODUCTION}

According to e.g. Eurobarometer (2012), when a robot is at work on a heavy, dangerous and difficult task, the robot is perceived to function in an important role and is met with a positive attitude by most people. In contrast, the attitude towards robots change to starkly negative when the robot is put to work on more "human" tasks, such as health care or personal wellbeing [2]. The latter negative attitude is unfortunate in that economic analyses point to an imminent need to develop service robots and care robots in e.g. elderly care. To potentially change such attitudes for the better, the general aim in this paper is to inquire into how to improve upon attitudes of a robot's functions and roles in healthcare and wellbeing for the elderly.

This paper describes and analyzes how and why future professionals, already while they are still studying, can function and have important roles in improving attitudes towards service robots. The paper enquires into 1) improving upon education to equip caregivers with a higher competence to work with robots, improving attitude, functions, and roles; 2) designing and improving robotic care and other digital services for the elderly, as well as 3) changing attitudes about such robotic care for the more positive. This paper pursues the above three aims through describing and analyzing a research-driven Master'slevel study course in a university of applied sciences. The research questions driving the academic research project underlying the study course were: what kind of useful functions and roles students can have in such an academic-research project and what ideas students can present for research questions "2)" and "3)", in particular?

Master's-level education in the context of the study

Generally, the aim of higher education in Finland has been to produce competences for working life through teaching, research and regional development. Among institutions of higher education, the tasks of universities of applied sciences (UAS) have emphasized competencebuilding and qualification for working life, in particular when it comes to UAS Master's-level education [3]. UAS Master's-level degree programmes (135 ECTS) have included substance-based studies, research methods studies, and a thesis. Laurea, a leading UAS in Finland, has offered 12 Master's-level degree programmes, three of which have been taught in English. The scope of a Master's degree at Laurea have included programme-specific studies for development of the core working-life competences in the student's chosen field of study, and a thesis of 45 ECTS credit points. The core competence has been supplemented by Laurea's portfolio of complementary studies, in which the student has been able to choose 45 ECTS credits worth of management and development studies as indicated by his/her personal needs and based on the personal curriculum. It has also been possible to select elective studies from the core studies of other programmes. [4]

\section{Expected competences}

In their literature review, Uerz et al (2018) have identified that there are at least four domains or levels of working-life competences, in all domains in which a current or professional can improve upon $[5,1]$ 
1.Technology competences, or an ability to use technology as such (related to learning for one's self or to teaching of others);

2. Competences for getting instrumental value from the use of technology as such, or pedagogical and educational skills for educating others on such instrumentality;

3. Beliefs about learning and teaching, or deriving symbolic value or meaning out of technology new or old;

4. Competences for innovation and professional learning; or being able to function and have roles across levels "1.", "2.", and "3.".

Among the above forms of professional development, beliefs, instrumentality and function, competences in using robotics in real-life environments, in particular, has been at its infancy [6]. According to Ortega-Navas (2016), contributions of robotics and other new technologies challenge the paradigm in terms of health promotion, in particular. New technologies challenge the traditional mission of health education as diagnosis and treatment by enabling improvement of quality of life and facilitating shared information and communication among health professionals and their patients [7]. Automatization and robotics in working life in the healthcare and social welfare field, thus, are a massive change now and in the not-too-far future.

\section{ROSE - Robots and Future of Welfare Services Research Project}

The academic research project: ROSE (Robots and Future of Welfare Services) is a Strategic Research Council, Academy of Finland, funded research project that began in 2015. This research project is based on a multidisciplinary and holistic approach to study how advances in robot and perception technologies allow product and service innovation and renewal of welfare services, developed jointly with users and other stakeholders. It enquires into how and why new services via robotics require study of ethical issues and stakeholder participation. The content of the ROSE acts on three levels: a) individual level (human-robot interaction, ethics); b) service level (welfare services with robots in different roles); and c) society level (societal acceptance, renewal of service systems). The consortium partners are: Department of Electrical Engineering and Automation, Aalto University Department of Signal Processing; Tampere University of Technology, School of Social Sciences and Humanities: University of Tampere, Business ecosystems, value chains, and foresight; VTT Technical Research Centre of Finland; Lappeenranta University of Technology.; as well as Laurea University of Applied Sciences and School of Business and Management. ROSE is coordinated by Aalto University and will run until the year 2020 [8].

The ROSE project aims to study the transformation of welfare services that is happening in tandem with the introduction of service robots to deliver such services. The focus is on elderly people's services, because of the challenge of ageing population in the society level. The transfer of technological possibilities and innovation chain are studied in the field of health and social welfare. The focus is on the disruption of present services and also on opportunities for new services [8]. ROSE's aim is to add multidisciplinary research work and to support stakeholders' and other actors' participation in applying robotics in elderly care and especially into the services of this field. Innovations 
are studied in and as the robotic ecosystem. The operationalization of the research questions in terms of working-life competence building include: how the work will change when robotics are integrated in working life? From the perspective of Laurea's participation in the study, the special focus is on real life situations and how societal acceptance to technical choices and robotic solutions are presented.

\section{METHODOLOGY}

The study presented in this paper is of qualitative nature and is based on action research and Living lab methodology. Action research is a methodological approach underlines that no key human individual in action research is ever a research object but also a research subject and active participant. The cyclic process of the action research is strongly anchored in a real life. Action research happens in a real life environment. The aim of action research is to change the specific real live environment under study, in this case a home for the elderly. The basic principles of action research are 1) practicality; 2) actors' participation and involvement; and 3) the creation of new activities or interventions related to a change. An action-research process is always practice orientated, based on a cyclic process of a) enabling; b) planning; c) implementation, and d) evaluation [9] or, to put it differently, a) inclusion; b) control; and c) intimacy [19].

Action research aims to produce new knowledge and new working models for practice. According to the literature, an action research can be seen as a method, a methodological approach, or both [9, 10]. Habermas' critical knowledge interest can be said for action research and production of new knowledge, new forms of actions, and new models of practices some of which may be best ones. The actionresearch process is emancipatory [11].

In this study, the cyclic process of action research is taken as one that is strongly learning-oriented $[9,10]$. We had students interview elderly people in their senior citizens' home in order to grasp the meaning of elderly people's ordinary day and their personal present situation of their life, thoughts on how the robot could be accepted in their everyday life. During their learning process, both these students and we ourselves were intensively immersed and engaged in the action research. The aim of both the students and us was to co create new and fresh ideas how to apply robots with and for the elderly. The Master's-level students who had their intensive study course in tandem with the ROSE academic research project; the students participated in planning, implementing the data collection for both ROSE and in the real-life home environment of the elderly people that they interviewed.

\section{Living Lab}

The definition of the concept of "living lab" is that it is a network of people, artefacts and a working environment that integrates usercentered research and open innovation [12]. Leminen and Westerlund define living labs as physical regions or virtual environments. The basic principles of a living-lab approach are congruent with an actionresearch one [14]. In both of these approaches, a critical knowledge interest is seen as the basis. Similary to action research, a living lab can be made manifest either as a method or as a methodological approach [12]. The aim of a living lab is to examine and study the phenomena in real life contexts through the research process and real life actions [13]. Living-lab research aims also for change. The 
research actions are related to the concept of change [9] and the aim of living-lab research is to solve problems and to find out new solutions. Typically an enabler-driven living lab enables actors to represent in new ways themselves to one another, e.g. in the public sector: muncipalities, non-govermental organizations, and financiers $[12,13]$. Regional or societal needs are often in focus in living labs.

In living-lab research, professionals in the healthcare and socialwelfare field have been provided access to the latest information of health technology and robots when testing the products in development environments or direct in their own work. The focus on inquiry was the extent that this kind of testing added to their competence in using health technology and adding positive attitudes towards health technology. Educational institutes and universites have been the actors in provider-driven living labs where research, education and knowledge transfer have been in interaction. A provider-driven living lab has been found to consist of experts' knowledge and competences. Enablers have been found to make possible physical environments as living labs. User-driven living labs have been found to based on users or user communities where solutions for everyday life problems are investigated and discovered. Actions and activities in user-driven living labs have been found to be informally organized along process organized from the bottom-up $[12,13]$.

In this paper, living lab as a methodological approach and as a real live environment offer a context in which Master's-level students' roles as professionals competent in the future has been studied. The phenomena of service robots and development of business concepts were studied through the orientation of research and in the process of real life setting. This context served as the study-course platform and a learning environment for the students. Co-creation and co-design together with different actors included students, researchers, professionals and elderly people, provided new possibilities to study and achieve new competences when developing robotics to support user's health and wellbeing, new services and as well as developing the working life. For the Master's-level students, living-lab methodology and action research approach were the basis for participation in ROSE project. The living-lab arrangement stimulated interaction between students and other actors. In addition, creative methods for facilitation supported participation and involvement during the implementations of the course. Sipoo, a small community in southern part of Finland served as the project's living lab environment. In the ROSE project, elderly people as clients and home care workers as professionals were the key actors and key human individuals in developing robots in elderly care field.

The purpose and research questions

This paper focuses on students' perspective during the ongoing ROSE project. The aim was to describe student's roles and their ideas of how to apply robots in health and social welfare field. The article answers the following questions: what kind of roles students can have in an academic-research project and what kind of ideas can they present for how robots ought to deliver services and/or care for the elderly? 


\section{Participants}

Students $(n=36)$ came from a wide array Master's degree programs within Laurea: Service Innovation and Design, Security Management, as well as Leadership and Management in Health care and Social Welfare. The students represented different future work-life careers such as those in health care, social welfare, management and leadership in health and social welfare, security and emergency service, tourism, as well as insurance.

The data collection methods and the data analysis

The data included survey from health care and social welfare Master's-level students $(n=28)$ participating in the course of digital services, and the data from the students $(n=8)$ participating in joint intensive course of Research, Service robots and Concept Development (five credits). The idea of joint course was that students are participating in planning, implementing and evaluating how to apply robots, particularly a social humanoid robot, in elderly care in order to respond elderly people's needs, such as loneliness, unsafety and immobility.

Reflections and discussion during the intensive course and during the data collection in real life situations as a living lab context were used as the data for the study presented in this article. The data included students' written answers to the themes: what kind of ideas for using robots in their own work, an thoughts on required and expected competences when robots are used. The data was analyzed using inductive content analysis $[15,16]$ through mapping and categorizing the subthemes and themes for identifying the types and profiles of roles.

\section{RESULTS}

The data included survey from healthcare and social-welfare Master'slevel students participating in the study course of digital services and especially the data from the Master's-level students from different fields participating in joint intensive study course. The process and reflections of eight students during the intensive joint course, in particular, offered rich content for the data analysis and findings of this study.

As analyzing the data, we found that the students were activly participating in the process in ways where their roles did not become homologous through to peer pressure but, rather, were and remained highly diverse. Our interpretation of this is that the students, who were not intimately immersed in the established systems in the elderly home, could skip phases of inclusion or exclusion, control or being controlled, and could jump directly into the final phase of intimacy with the challenges at hand, and reaching out to solutions. In other words, unburdened by socio-psychological needs for diagnosis and planning based on their evaluations of the status quo, as is common to insider participants to issues treated through action research, the students moved fluidly and directly into the implementation phase. The students, so to speak, were emancipated by virtue of never being part of the "total institution" as are "inmates" to an elderly home.

The types of the roles that emerged from the student-related data were based on the participation of both us and them in the joint study course, and on our survey of their views on what kinds of ideas and 
what kinds of competences will be needed with the introduction and mainstreaming of robotics in elderly homes and elderly care. The active participation in the joint course of both the students and us enabled their engagement and cooperation with various actors in real life situations as with the elderly people, with the staff members, and, obviously, with us as researchers. The students were able to cooperate authentically in multiprofessional team and learn from each other. Through the participation in multiprofessional teamwork and with the elderly people in the project, the students learned to grasp the value of a future orientated and user-centered approach to develop working life competences in how to apply robotics into services and care. Studying and learning in the ROSE academic research project enhanced and multiplied the array of the kinds of roles they adopted, as well as the kinds of competences that they began to develop, for themselves.

The roles and competences that we found them to work on for themselves included being or becoming: 1) a developer, 2) an innovator, 3) an explorer, 4) a follower, and/or 5) a doubter (Table 1).

Table 1. Summary of the roles

\begin{tabular}{|c|c|c|c|c|c|}
\hline $\begin{array}{l}\text { Perspectives } \\
\text { of the } \\
\text { themes } \\
\text { Robotics } \\
\text { /Living lab }\end{array}$ & Developer & Innovator & Explorer & Follower & Doubter \\
\hline $\begin{array}{l}\text { description } \\
\text { of } \\
\text { role and } \\
\text { actions }\end{array}$ & $\begin{array}{l}\text { reflects and } \\
\text { applies on } \\
\text { her/his own } \\
\text { work }\end{array}$ & $\begin{array}{l}\text { invents and } \\
\text { produces a } \\
\text { lot of ideas } \\
\text { motivates }\end{array}$ & $\begin{array}{l}\text { searches and } \\
\text { hunts may } \\
\text { possibilities } \\
\text { critical } \\
\text { thinking }\end{array}$ & $\begin{array}{l}\text { follows and } \\
\text { repeats the } \\
\text { others' } \\
\text { thoughts and } \\
\text { actions }\end{array}$ & $\begin{array}{l}\text { slowly } \\
\text { interested } \\
\text { first } \\
\text { thought: } \\
\text { not for } \\
\text { me or us }\end{array}$ \\
\hline ideation & $\begin{array}{l}\text { new ideas for } \\
\text { using robots } \\
\text { in everyday } \\
\text { life } \\
\text { at work } \\
\text { and ideas for } \\
\text { many tasks in } \\
\text { working field }\end{array}$ & $\begin{array}{l}\text { rich ideas for } \\
\text { various } \\
\text { clients ( } \\
\text { during life } \\
\text { span) on } \\
\text { wide areas } \\
\text { and } \\
\text { environments }\end{array}$ & $\begin{array}{l}\text { ideas for } \\
\text { applying } \\
\text { robots with } \\
\text { clients, with } \\
\text { staff } \\
\text { members and } \\
\text { in many } \\
\text { environment } \\
\text { for various } \\
\text { actions }\end{array}$ & $\begin{array}{l}\text { few task } \\
\text { orientated } \\
\text { ideas }\end{array}$ & $\begin{array}{l}\text { only few } \\
\text { ideas if } \\
\text { any }\end{array}$ \\
\hline competence & $\begin{array}{l}\text { programming, } \\
\text { coding, } \\
\text { technological, } \\
\text { how to } \\
\text { handle with a } \\
\text { change }\end{array}$ & $\begin{array}{l}\text { innovation, } \\
\text { coding, } \\
\text { cooperation } \\
\text { with coders } \\
\text { and } \\
\text { designers } \\
\text { ICT skills. } \\
\text { safety }\end{array}$ & $\begin{array}{l}\text { programming, } \\
\text { coding, } \\
\text { technical and } \\
\text { technological } \\
\text { what is } \\
\text { possible, } \\
\text { what is not } \\
\text { ethical } \\
\text { competence }\end{array}$ & $\begin{array}{l}\text { technical, } \\
\text { technological, } \\
\text { coding, }\end{array}$ & technical \\
\hline
\end{tabular}

Among these roles and emerging competences, it appear that being a developer focuses on person's own line of work, on the organization they work for, and on the working environment. This kind of a working model is quite tight concerning tasks, roles and competences of others. A developer role widens a little bit one's thinking out of the box. 
In partial contrast, it appears that an innovator is a very active participant, capable of thinking and producing new ideas and opportunities. Innovator is quickly inspired. Innovator is bot rich in ideas and has a wide perspective. An innovator reflects their ideas for using robots with and for various clients or environments.

Curiosity is the basis of an explorer. An explorer represents researchorientated mindset who is actively ideating but also critically assesses the possibilities.

A follower listens most actively to others and repeats other participants' thoughts and ideas. A follower is prone to continue other person's sentences and suggestions.

A doubter represents slow idea generation and shows little interest towards any topic or theme. A doubter suspects whether there are any benefits or utility in a proposal, in this case, using robots.

Technical and technological competence, safety competence, attitudes and approach competence, ethical competence and qualifications are categories from produced and needed competences of how to deal with robots. Technological competence means programming and coding robots and contents. Technical refers to mechanisms, disturbances and maintenance services of robots or advices. Safety competences includes e.g. safety and security of the robot as a technical device. Attitudes includes positive or negative stance towards approach to work. Ethical competence includes critical thinking of good or bad perspective when using robots, evidence of decision making and humans' self-determination.

\section{CONCLUSIONS}

In terms of how to work towards emancipation [11], this paper has taken that education is crucial, also when applying robots in health care and social-welfare fields, for improving upon attitudes towards new ICT applications, digital services, and e-learning. [9, 10, 12, 13, 14]. We find that students' participation and interaction with professionals is key to thinking outside the box and thus learning new ways of working and getting new ideas $[1,5,7 ; 10 ; 17]$. Taking inspiration from our academic-research subjects, from Habermas, as well as from academic research on action research and on living labs, we find that there is a need for more than one role and competence in exploring robots and the future of healthcare and wellbeing services. These, we believe, relate to enabling; planning; implementation; and evaluation of a working environment with developers and innovators. Working is such a setting enables one to develop an attitude conducive to new ideas and models, and to changing old ones.

Clients' or patients' active participation and involvement are key ingredients in planning for change. Such participation is key to successful implementation and coming up with a new course of action that attracts followers. Evaluating success as success is in other words a course of action warding off and keeping away doubters [17]. When the virtuous-cyclical course of action spreads, a new course of action for massive change is in motion. This can compound into new products, services, applications or models through a co-creation process [18]. In the way proposed in this paper, students and future professionals with new roles and new competences more readily than clients or established professionals emerge with new roles and 
competences. Unburdened with identification with "the system" or status quo, they are more emancipated from the start than are clients or students. They focus less on evaluation and diagnosis, or questions of inclusion or exclusion or control, and move more directly into implementation.

An interesting future topic will be how robots, perhaps equally uninstitutionalized to students, will become equally legitimate actors in comparison to the students. Another future challenge will be to study more how robots will change our present work life and how education should respond. The need for future studies about ethical issues is evident.

\section{REFERENCES}

[1] J Tondeur, J Van Braak, S Guoyuan, J Voogt, P Fisser and A.S Ottenbreit-Leftwich, Preparing student teachers to integrate ICT in classroom practice: A synthesis of qualitative evidence. Computers \& Education, 59(1), 134-144, 2012.

https://doi.org/10.1016/j.compedu.2011.10.009

[2] Special Eubarometer 382, 2012.

http://ec.europa.eu/public_opinion/archives/ebs/ebs_382_en.pdf.

[3] Finnish Act of University of Applied Sciences. FINLEX. https://www.finlex.fi/fi/laki/ajantasa/2014/20140932?search\%5Btype\%5D=pika\&search\%5Bpika $\% 5 \mathrm{D}=14.11 .2014 \% 2 \mathrm{~F} 932$

[4] Laurea University of Applied Sciences, Master's Degree Programmes, 2017. https://intra.laurea.fi/en/laurea/studyprogrammes/master/Pages/default.aspx

[5] D Uerz, M Volman and M Kral, Teacher educators' competences in fostering student teachers' proficiency in teaching and learning with technology: An overview of relevant research literature. Teaching and Teacher Education Vol 70, 12-23, 2018.

[6] M Ortega-Navas, The use of new technologies as a tool for the promotion of health. 7th International Conference on Intercultural Education "Education, Health and ICT for a Transcultural World", EDUHEM 2016, 15-17 June 2016, Almeria, Spain, 2017.

https://ac.els-cdn.com/S187704281730006X/1-s2.0-S187704281730006Xmain.pdf?_tid=e2b8ba5c-f861-11e7885800000aacb35d\&acdnat=1515848676_6043ff7afdaf61d13c22ae8c2ad14d6f

[7] H Bai and P.A Ertmer, Teacher educators' beliefs and technology uses as predictors of preservice teachers ' beliefs and technology attitudes. Journal of Technology and Teacher Education, 16 (1), 93 - 112, 2008.

[8] Robots and future of welfare services (ROSE) http://roseproject.aalto.fi/ https://ac.els-cdn.com/S0742051X17304936/1-s2.0-S0742051X17304936main.pdf?_tid=1dd10a4a-f85d-11e7-a43200000aabOfo2\&acdnat=1515846627_818b83faf64ae9cde4b36c64a01be1a6

[9] J. Moore, K., Crozier. \& K. Kite, An action research approach for developing research and innovation in nursing and midwifery practice: Building research capacity in one NHS foundation trust. Nurse Education Today (32):39-45, 2012.

[10] P Reason and H Bradbury, The Sage Handbook of Action Research: Participative Inquiry and Practice. 2nd edition. Sage Publications Ltd. London, 2008.

[11] J Habermas, Knowledge and human Interests. Heinemann, London, 1972.

[12] S Leminen, Living Labs as open innovation networks. Aalto University publication series. Doctoral Dissertations 132/2015. Unigrafia Oy, Helsinki, 2015. https://aaltodoc.aalto.fi. 
[13] S Leminen, M Westerlund and A-G Nyström, On Becoming Creative Consumers - User Roles in Living Labs Networks. International Journal of Technology Marketing, 9(1): 33-52, 2014. http://dx.doi.org/10.1504/IJTMKT.2014.058082

[14] D Schuurman, L D,Marez and P Ballon, The impact of Living Lab Methodology on open innovation contributions and outcomes. Technology Innovation Management Review, 7-16, 2016.

http://timreview.ca/sites/default/files/article_PDF/Schuurman_et_al_TIMReview_January2016.p df

[15] M Patton, Qualitative evaluation and research methods. Sage, Beverly Hills, California, 1990.

[16] I Dey, Qualitative data analysis: a user-friendly guide for social scientists. Routledge, London, 1993.

[17] M Pallot, B Trousse, B Senach and D Scapin. Living Lab Research Landscape: From User Centred Design and User Experience towards User Cocreation. First European Summer School "Living Labs" Paris, France, 2010. https://hal.inria.fr/file/index/docid/612632/filename/LLResearch-Landscape-and-UGX.pdf

[18] S Hyysalo, Käyttäjä tuotekehityksessä - Tieto, tutkimus, menetelmät. (User in product development - Knowledge, Research, Methods). University of Art and Design publications B 97. Helsinki. 2009.

[19] P.G. Wicks and P Reason. Initiating action research: Challenges and paradoxes of opening communicative space, Action Research, 7(3): 243-262, 2009. 